\title{
PERANAN WILAYAH DALAM PENGEMBANGAN KURIKULUM
}

\author{
Dr. Masriam Bukit
}

\begin{abstract}
:
Desentralisasi terjadi di berbagai bidang termasuk dalam bidang pendidikan. Alasan utama diberlakukannya desentralisasi dalam pendidikan adalah bahwa bila wilayah (propinsi, kabupaten atau kota) mendapat otonomi lebih besar dalam pengambilan keputusan, wilayah berikut kepala sekolah dan guru-guru akan mulai mengontrol kurikulum serta proses pengajaran di sekolah. Desentralisasi membuka ruang yang lebih baik kepada daerah untuk mengontrol pendidikan, serta diharapkan akan semakin besar fleksibilitas dalam pendidikan. Daerah juga memiliki peluang untuk mengembangkan pendidikan sesuai dengan kebutuhan dan potensi daerahnya. Proses desentralisasi pendidikan dibagi kedalam dua tahap. Tahap pertama, pemindahan kewenangan kebijakan pendidikan dari pemerintah pusat ke pemerintah daerah.Tahap kedua,pemindahan berbagai keputusan dari pemerintah kepada masyarakat.
\end{abstract}

\section{Keywords :}

Desentralisasi, fleksibilitas, kewenangan daerah

\section{Pendahuluan}

Ada dua masalah besar yang dihadapi oleh dunia pendidikan di Indonesia, yakni, masalah globalisasi dan otonomi daerah. Globalisasi yang ditandai dengan persaingan atau kompetisi yang sangat keras, dan globalisasi yang ditandai oleh investasi, produksi, dan inovasi yang melintasi batas-batas negara.
Globalisasi membawa perubahan dunia kerja serta pada gilirannya membawa reformasi terhadap dunia pendidikan di Indonesia.

Otonomi daerah atau desentralisasi yang digulirkan pada tahun 1999 menyerahkan sebagian besar pengambilan keputusan dari pusat ke daerah. Dalam bidang pendidikan, 
pusat hanya mengurusi hal-hal yang strategis pada tatanan nasional. Desentralisasi memberi tanggung jawab baru dalam bidang pendidikan kepada wilayah. Desentralisasi membawa perubahan terhadap dunia pendidikan di Indonesia.

Kurikulum sebagai bagian dari sistem pembelajaran adalah salah satu aspek yang sangat terkena dampak desentralisasi. Semua pedoman semula dikeluarkan dari pusat, setelah desentralisasi wilayah harus memikul sebagian besar dari tanggung jawab tersebut. Konsekuensinya wilayah harus mengembangkan kurikulum sesuai dengan kebutuhan wilayahnya. Wilayah harus pula mempelajari apa yang menjadi peranan wilayah dalam pengembang-an kurikulum.

\section{Desentralisasi Pendidikan}

Desentralisasi pendidikan terjadi sebagai konsekuensi logis dari diberlakukannya UU No.22 tahun 1999, serta pp No. 25 tahun 2000. Desentralisasi pada hakekatnya bertujuan untuk memberi kekuasaan lebih besar dalam pengambilan keputusan kepada wilayah., Sistem pemerintahan yang sentralistik mengakibatkan beban menjadi berat ke pemerintah pusat. Dengan desentralisasi beban tersebut didistribusikan ke daerah-daerah. Beban pemerintah pusat berkurang, dan sebagai penggantinya, pemerintah daerah beserta masyarakat ikut menanggung beban tersebut. Desentralisasi terjadi diberbagai bidang termasuk dalam bidang pendidikan. Alasan utama diberlakukannya desentralisasi dalam pendidikan adalah bahwa bila wilayah (propinsi, kabupaten atau kota) mendapat otonomi lebih besar dalam pengambilan keputusan, wilayah berikut kepala sekolah dan guru-guru akan mulai mengontrol kurikulum serta proses pengajaran di sekolah. Daerah mulai memikul tanggungjawab terhadap implementasi sistem pembelajaran, terhadap peningkatan mutu guru, pengangkatan kepala sekolah, serta pengembangan kurikulum. Desentralisasi membuka ruang yang lebih baik kepada daerah untuk mengontrol pendidikan, serta diharapkan akan semakin besar fleksibilitas dalam pendidikan. Asumsinya adalah bahwa dengan meningkatnya kontrol serta fleksibilitas diharapkan proses pendidikan yang dilaksanakan disekolah semakin memenuhi dengan tuntutan orang tua dan masyarakat, sekaligus semakin besar pula akuntabilitas pendidikan. Desentralisasi pendidikan juga memberi keuntungan bagi peningkatan efisiensi dan partisipasi.

Proses desentralisasi pendidikan memiliki landasan pemerataan dan 
efisiensi. Namun desentralisasi perlu ditopang oleh sistem demokrasi pada tingkat wilayah. Tanpa demokrasi desentralisasi kemungkinan besar akan menumbuhkan sistem yang dikuasai oleh kelompok elite pada tingkat wilayah.

Apa yang terjadi pada desentralisasi pendidikan diberbagai negara, sering bukan untuk memberi otonomi lebih besar kepada guru dan sekolah, tetapi cenderung untuk mengontrol apa yang dilakukan guru. Bukan untuk meningkatkan kualitas sekolah, tetapi lebih untuk mengurangi kontrol pemerintah pusat terhadap keuangan, dan pengelolaan sumber-sumber daya pendidikan di wilayah.

\section{Pengembangan kurikulum dalam era desentralisasi pendidikan}

Kebijakan pengembangan kurikulum diberbagai negara sangat beragam. Negara dengan tradisi desentralisasi yang kuat seperti Amerika Serikat otoritas pengembangan kurikulum didelegasikan kepada daerah, kepada negara-negara bagian. Negaranegara bagian memiliki sistem kebijakan kurikulum yang beragam. $\mathrm{Di}$ Republik Federasi Jerman misalnya, yang juga memiliki sistem negara bagian (lander) menganut sistem pengembangan kurikulum yang terbagi kurikulum nasional dan kurikulum negara bagian. Kurikulum pusat disusun oleh pemerintah federal, dan kurikulum negara bagian disusun oleh pemerintah negara bagian. Kurikulum federal digunakan diseluruh negara, sedangkan kurikulum di negara bagian hanya berlaku pada negara bagian (lander) tersebut. Kebijakan pengembangan kurikulum di Indonesia memiliki kemiripan dengan kebijakan pengembangan kurikulum diberbagai negara. Terdapat kurikulum komponen nasional dan ada pula kurikulum komponen muatan lokal.

\section{Peran wilayah dalam pengembangan Kurikulum}

Proses desentralisasi pendidikan pada dasarnya bertujuan meningkatkan mutu pendidikan di wilayah. Melalui desentralisasi pendidikan diharapkan daerah memiliki peluang untuk mengembangkan pendidikan sesuai dengan kebutuhan dan potensi daerah.

Mutu dipengaruhi oleh serangkaian proses dan kegiatan yang saling terkait. Proses desentralisasi pendidikan dibagi kedalam dua tahap (Fasli Jalal dkk, 2001). Tahap pertama, pemindahan kewenangan kebijakan pendidikan dari pemerintah pusat ke pemerintah daerah.Tahap kedua,pemindahan berbagai keputusan dari pemerintah kepada masyarakat. Burki et al. (1999) menyaran- 
kan aspek-aspek pendidikan yang dapat didesentralisasikan adalah: sistem pembelajaran, manajemen personalia, perencaaan dan struktur, serta sumber daya. Salah satu jenis keputusan yang dapat didesentralisasikan dari aspek sistem pembelajaran adalah pengembangan kurikulum. Berkaitan dengan proses pengembangan kurikulum, wilayah memiliki peran sangat sentral dan strategis. Kepala Dinas Pendidikan perlu melakukan langkah-langkah persiapan berupa rencana strategis bagi pengembangan kurikulum di wilayahnya.

Terdapat sejumlah kegiatan strategis diseputar pengembangan kurikulum yang perlu dipersiapkan sehubungan dengan desentralisasi kurikulum, (Glatthorn,1994). Dia mengetengahkan terdapat sejumlah kegiatan yang menjadi tanggung jawab wilayah, yaitu: pembentukan komite pengembang kurikulum wilayah, peletakan landasan-landasan, perumusan panduan pengembangan kurikulum, menyusun dan mengatur strategi implementasi yang efektif, audit kurikulum guna menjamin mutu.

Komite pengembang kurikulum wilayah, dimaksudkan agar masyara-kat ikut mengurus kurikulum di wilayahnya. Anggotanya merupakan representtatif dari masyarakat di wilayah tersebut. Komite pengembang kurikulum wilayah bertanggungjawab terhadap kebijakan kurikulum (curriculum policy) di wilayah tersebut termasuk pembentukan perencana kurikulum, satgas kurikulum,penulis kurikulum, serta penulisan panduanpanduan sistem pembelajaran di daerahnya.

\section{Daftar Pustaka}

Carnoy, M., (1999). Globalization and Educational Reform: What Planners Need to Know. Paris: UNESCO/IIEP.

Fasli J. dan Supriadi, D., (2001). Reformasi Pendidikan dalam Konteks Oto-nomi Daerah. Yokyakarta: Adicita Karya Nusa.

Glatthorn A. (1994). Developing A Quality Curriculum. Alexandria: ASCD.

UNESCO. (2002). Education for Rural Development in Asia. Experiences and Policy Lessons. Paris: UNESCO 